\title{
Systems of Nominal Classification in East Papuan Languages
}

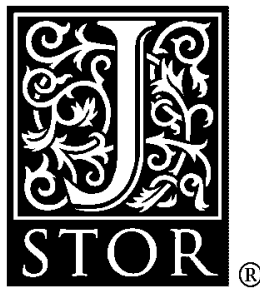

\author{
Angela Terrill
}

Oceanic Linguistics, Vol. 41, No. 1. (Jun., 2002), pp. 63-88.

Stable URL:

http://links.jstor.org/sici?sici=0029-8115\%28200206\%2941\%3A1\%3C63\%3ASONCIE\%3E2.0.CO\%3B2-H

Oceanic Linguistics is currently published by University of Hawai'i Press.

Your use of the JSTOR archive indicates your acceptance of JSTOR's Terms and Conditions of Use, available at

http://www.jstor.org/about/terms.html. JSTOR's Terms and Conditions of Use provides, in part, that unless you have obtained prior permission, you may not download an entire issue of a journal or multiple copies of articles, and you may use content in the JSTOR archive only for your personal, non-commercial use.

Please contact the publisher regarding any further use of this work. Publisher contact information may be obtained at http://www.jstor.org/journals/uhp.html.

Each copy of any part of a JSTOR transmission must contain the same copyright notice that appears on the screen or printed page of such transmission.

The JSTOR Archive is a trusted digital repository providing for long-term preservation and access to leading academic journals and scholarly literature from around the world. The Archive is supported by libraries, scholarly societies, publishers, and foundations. It is an initiative of JSTOR, a not-for-profit organization with a mission to help the scholarly community take advantage of advances in technology. For more information regarding JSTOR, please contact support@ jstor.org. 


\title{
Systems of Nominal Classification in East Papuan Languages
}

\author{
Angela Terrill
}

\author{
AUSTRALIAN NATIONAL UNIVERSITY
}

\begin{abstract}
The existence of nominal classification systems has long been thought of as one of the defining features of the Papuan languages of island New Guinea. However, while almost all of these languages do have nominal classification systems, they are, in fact, extremely divergent from each other. This paper examines these systems in the East Papuan languages in order to examine the question of the relationship between these Papuan outliers. Nominal classification systems are often archaic, preserving older features lost elsewhere in a language. Also, evidence shows that they are not easily borrowed into languages (although they can be). For these reasons, it is useful to consider nominal classification systems as a tool for exploring ancient historical relationships between languages. This paper finds little evidence of relationship between the nominal classification systems of the East Papuan languages as a whole. It argues that the mere existence of nominal classification systems cannot be used as evidence that the East Papuan languages form a genetic family. The simplest hypothesis is that either the systems were inherited so long ago as to obscure the genetic evidence, or else the appearance of nominal classification systems in these languages arose through borrowing of grammatical systems rather than of morphological forms.
\end{abstract}

I. BACKGROUND. ${ }^{x}$ The languages to be evaluated, the East Papuan languages, include all but one of the non-Austronesian languages spoken in the islands off the east of mainland New Guinea (one language, Kovai, spoken on Umbai Island, off the coast of mainland Papua New Guinea, is clearly of the Trans New Guinea Phylum [Ross 200I:30I]). The East Papuan languages as a whole are currently considered as a group in this paper solely on the basis of their geographical proximity.

The best known classification of East Papuan languages is that of Wurm (I982: 23 I-244, basically repeated from Wurm I975), while a more recent classification comes from Ross (200I). Ross (to appear, b) is a fuller treatment of the same data. Wurm's classification is based mainly on lexical and typological features including "verb systems and forms, gender systems and the form of the gender markers,

I. Thanks to Malcolm Ross, Eva Lindström, Ger Reesink, and Michael Dunn for comments on an earlier draft of this paper. Thanks also to Eva Lindström and Malcolm Ross for kindly giving permission to cite their unpublished work. I am also grateful to the Max Planck Institutes in Leipzig and Nijmegen for supporting this work.

Oceanic Linguistics, Volume 41, no. I (Junc 2002)

(C) by University of Hawai'i Press. All rights reserved. 
etc." (Wurm I982:23I). However, Wurm does not indicate the data on which his analysis was based, and at least one of the languages included (Kazukuru) became extinct before grammatical data were available on it. It appears that some languages were included in the genetic classification simply because of their geographical location, rather than because of specific shared features.

Malcolm Ross has revived interest in this area recently, using the comparative method to undertake a comparison of the pronoun systems of these languages (Ross 200I; to appear, a; to appear, b), and on that basis argues for eight separate genetic groups. Ross leaves out of his analysis the languages of Reefs-Santa Cruz, on the grounds that they have had complex contact histories with Austronesian and Papuan mixing (to appear, b). This notwithstanding, he still states that "they have no genealogical relationship to any other east Papuan group" (200I:3IO).

Figure I in Dunn, Reesink, and Terrill (2002) (3I) compares Wurm's and Ross's classifications. The two concur in many of the lower-level groupings, but differ significantly in that for Wurm all the East Papuan languages belong in one genetic grouping, while for Ross there are eight separate genetic groups involved. Dunn, Reesink, and Terrill (2002) examine various linguistic features, including clausal and NP constituent order, pronominal systems, and the structure of verbal morphology, and conclude that these grammatical subsystems show clear similarities between Anêm and Ata (New Britain), and also between some of the languages of Bougainville, but not for the East Papuan languages as a whole. The present paper focuses on the smaller subsystem of nominal classification, with a view to elucidating the same questions.

The East Papuan languages have long been characterized by the presence of gender in an area of the world in which gender is otherwise scarcely present; Oceanic languages largely lack gender. For Wurm, gender was one of the defining features of the East Papuan languages as a genetic grouping. Others also took it as a noteworthy and characteristic feature. For instance, Capell cites noun classes with concord as one of the four features shared by the non-Austronesian languages of Island Melanesia (1962:37I).

Ross concurs with this view of the existence of gender as being indicative of some sort of relationship between these languages, although he cautiously does not commit to whether its existence in these languages is indicative of genetic inheritance or contact: "What the shared occurrence of gender suggests, therefore, is that the east Papuan region was once a linguistic area characterized by the presence of gender" (200I:3 I2).

The aim of this paper is to test the validity of Wurm's and Capell's hypotheses about the relationship between the East Papuan languages by exploring further the grammatical category that both of them took as evidence of the relationship. Even if gender, or more broadly, nominal classification, proves not to be indicative of genetic relationship, the extent of Ross's more cautious position is still worth further examination.

To show a relationship of common origin due to inheritance, or indeed even contact, we would want to find certain commonalities in the forms used to mark gender, or in the systems themselves. If we do find such similarities, we can use these to confirm Wurm's and Capell's hypotheses. If no commonalities are found between 
the gender systems of these languages, we cannot use the presence of gender as a criterion for the relationship (by genetics or contact) of the East Papuan languages. If commonalities are found, then it is important to examine them to see whether they are indicative of genetic inheritance or contact. This topic is revisited in section 4.

It is important to point out, in this context, that nominal classification is not unknown in Oceanic languages. Possessive classes are widespread (Lynch I998: I22I24), and numeral classifiers occur in Micronesian languages and Admiralty Islands languages (Lynch 1998: I I8). Gender occurs in some Oceanic languages, including in some of the Oceanic languages of the Island Melanesia region (see section 4).

Section I of this paper has given background information: a survey of the languages and sources, and an examination of previous classifications of East Papuan languages. Section 2 outlines the definitions of nominal classification, gender, and noun class to be used throughout the paper. Section 3 describes in detail the nominal classification systems of each East Papuan language, and section 4 discusses the results of the study and concludes that, while most of the East Papuan languages do have some form of nominal classification system, only a few of them can be shown to be related, and only in lower-level groupings.

\section{TYPES OF NOMINAL CLASSIFICATION: GENDER AND CLASSIFI-}

ERS. There are two separate subtypes of nominal classification that are of relevance to the languages described in this paper: classifier systems and gender.

Gender is a system of dividing nouns into morphological classes that determine agreement phenomena. Gender is obligatory, and is a feature of every single noun in the languages that have it. I follow Corbett's (I99I) definition of gender, in which gender is seen as a type of nominal classification that has the defining feature of causing agreement. That is, gender is "reflected beyond the nouns themselves in modifications required of 'associated words"' (Corbett 1991:4) (see also Grinevald 2000).

Included at the periphery of this definition of gender are languages that have natural gender distinctions only in third person pronouns. Such languages show marginal agreement in anaphoric reference (Corbett 1991:5), but are less interesting for our purposes, which are to investigate nominal classification and its morphological ramifications in the grammar of these languages. Note however that included in the term gender as it is used here (and defined by Corbett) is what have traditionally been called "noun classes." That is, any system that creates agreement classes in nouns is included as gender, whether that system distinguishes between sex, or humanness, or even between a large number of different classes.

For classifier systems, this paper follows Grinevald's (2000) typology, in which noun classifier systems, like gender, serve to classify nouns into groups. However, noun classifiers differ from gender in that they are not involved in agreement. Further, not all nouns in languages with classifier systems have classifiers, and classifiers are not always obligatory with nouns. There are generally a largish, open-ended number of classifiers in languages that have them. They are generally not affixed to the noun but are typically expressed by an independent lexical element. They are marked only once 
per clause, and speakers can choose for many or all nouns which classifier to use with an instance of a noun (Grinevald 2000:62, based on Dixon 1982, 1986).

Within the general category of nominal classifiers, Grinevald distinguishes between four types: numeral classifiers, noun classifiers, genitive classifiers, and verbal classifiers. The first three are evidenced in East Papuan languages.

Numeral classifiers are used in quantitative expressions, typically occurring as bound morphemes on numerals and other quantifying words, and occasionally on demonstratives and adjectives (Grinevald 2000:63). Noun classifiers are less common than numeral classifiers. They usually occur as free morphemes in an NP with their head noun, and occur in nonquantifying expressions (Grinevald 2000:64-65). Genitive classifiers appear in possessive constructions, usually bound to the possessor, semantically classifying the possessed noun. Grinevald notes that this type of classification system usually only occurs with a select group of nouns-usually culturally salient items - and further that they "constitute a class akin to the 'alienable' nouns, to be determined for each language" (Grinevald 2000:66).

The distinction between languages with alienable/inalienable possessive constructions and languages with possessive noun classifiers systems is often unclear. Aikhenvald (2000:I37) quotes Nichols (1992:I34-I35) as calling an alienable/ inalienable distinction a "subtype of nonagreeing classification." Aikhenvald discusses differences between an alienable/inalienable opposition and relational classifiers, and shows that they are different phenomena, but she does not address the issue of what type of nominal classification system the alienable/inalienable opposition actually is. That is, while an alienable/inalienable distinction is clearly different from relational classifiers, where in the typology of nominal classification should an alienable/inalienable distinction reside? Nichols and Grinevald consider an alienable/inalienable distinction as part of a genitive classifier system, while noting, however, that often the inalienable/alienable distinction is morphologically marked within an agreement system rather than with classifiers.

Aikhenvald further distinguishes three types of classifiers occurring in possessive constructions: possessed classifiers, which categorize the possessed noun; relational classifiers, which "categorize the semantic nature of a relation between the possessee and the possessor" (2000: I 25); and the very rare possessor classifiers, which categorize the possessor noun.

Noun classifiers are actual morphemes. As Aikhenvald (2000:13) notes, classifiers occur in classifier constructions, which are "morphosyntactic units ... [that] require the presence of a particular kind of morpheme, the choice of which is dictated by the semantic characteristics of the referent of the head of a noun phrase." Not included in classifier systems, but yet another type of nominal classification, is the type of system in which, for instance, different numerals occur with different semantic types of nouns. There is no overt classifier morpheme (so these are not numeral classifiers), and it is not really an agreement system, yet there is a morphosyntactic reflection of a semantic categorization of nouns.

It follows from the foregoing that the term "nominal classification" is a general term that subsumes gender systems and classifiers and any other type of system in 
which nouns are organized into groups with morphological implications, and this is how the term will be used here. Although, in principle, strict definitional criteria are adopted here to distinguish between types of nominal classification, in practice, for many of the languages to be discussed, the source data are not adequate to enable a thorough understanding of the system discussed. More data from some of these languages might lead to major amendments to the type of nominal classification system attributed to the language.

3. SURVEY OF NOMINAL CLASSIFICATION SYSTEMS. This section describes the nominal classification systems found in each language for which there are data available. The amount of data cited on each language directly reflects the amount available, so some languages are described in much more detail than others. This leads to an uneven coverage, but seems more descriptively useful than restricting the amount of data discussed to conform to the amount available on the leastrecorded languages. The languages can be conveniently thought of in three groups, based on island location (New Britain/New Ireland, Bougainville, and the Solomon Islands), and this is how they are presented in the rest of the paper.

3.1 NEW BRITAIN/NEW IRELAND. Of the Papuan languages of New Britain and New Ireland, only Sulka shows no trace of a gender distinction (although it makes a distinction between possession of kinship terms versus other types of possession [Tharp 1996:80-8I]). In addition, two of these languages (Anêm and Ata) also have genitive classifier systems, and Baining has a noun classifier system.

Anêm. Anêm has a gender system involving two classes, called masculine and feminine. All nouns belong to one of these genders. All female beings are feminine; all male beings are masculine; and for other nouns, Thurston says they are "arbitrarily" assigned to one or other of the genders: "most trees, axes, and mountains are masculine, while most vines, the ocean, knives and houses are feminine" (Thurston 1982:45). There is also evidence of morphologically assigned gender: first and second persons take feminine agreement in the singular but masculine agreement in the plural, irrespective of the sex of the referent.

Gender is manifested in concord within the NP on deictics, and on subject and object verbal affixes in the wider clause. For example (from Thurston 1982:46):

(I) Doxa lêxa lêxîd u-kon u-k. ${ }^{2}$ person M.former M.over.there he-go he-go 'The man who was over there has gone away.'

(2) Doxa sêxa sêxîd i-kon i-k. person F.former F.over.there she-go she-go 'The woman who was over there has gone away.'

2. Abbreviations: ARTicle; Collective; DIMinutive; DUal; EFOC: focus marker from heo paradigm; EXCLusive; Feminine; FOC: focus marker from feo paradigm; LIGature; Masculine; Neuter; PLural; POSsessive; PROximal; sUBJect; SG: singular; TAM, tense, aspect, and modality. 
There is also a system of genitive classifiers: that is, nouns can be divided into classes on the basis of their possessive morphology. These possessive noun classes are independent of genders (46). There are twenty possessive classes (37). Semantic associations are unclear in most cases. The examples Thurston gives appear to be what Aikhenvald (2000) calls relational classifiers:

(3) a. êdîn-at 'my coconut (to eat)'

b. êdîn-n-ai 'my coconut (tree that I planted)'

c. aba-k-e 'my pig'

d. aba-i-at 'my pork'

e. ki-l-e 'my hair (head)'

f. ki-n-e 'my hair (pubic)'

g. ki-g-a 'my hair (body)' (Thurston 1982:37)

Anêm's Austronesian neighbor Lusi has some almost identical possessive classes, apparently borrowed from Anêm's much larger set. The Lusi ones are simpler, though, and contain fewer paradigms and no irregularities (Thurston I982:37).

Ata. There are two genders, feminine and nonfeminine (Hashimoto [n.d.] calls them masculine/neuter and feminine; Yanagida [2000] calls them masculine and feminine), and there is also a system of genitive classifiers. The genders are based on sex; all female referents are feminine, all other referents are nonfeminine. Gender is shown on third-person subject prefixes and object suffixes on verbs, and also in third person free pronoun forms.

In the genitive classifier system, possessive suffixes mark person and number of possessor, and the class of the possessed item:

(4) a. uala-silo name-my 'my name' (Class I)

b. viso-xeni knife-my 'my knife' (Class 2)

c. vu'a-xo betelnut-my 'my betelnut'(Class 3)

d. opo-leli belly-my 'my belly' (Class 4) (Hashimoto n.d.:8)

There are four classes. They are relatively transparent semantically: Class I are "relatively stationary entities with a more permanent location". Class 2 are "relatively portable entities with a more frequently changing location"; Class 3 are consumable. Class 4 are body parts and kinship terms only (the fourth class contains many subclasses) (Hashimoto n.d.: I 2). Note that some nouns can occur in Classes I, 2, or 3 to express slightly different meanings:

(5) a. memee-xeni pig-my 'my pig which I keep'

(Class 2)

b. memee-xo pig-my 'my pork' 
c. lavo'o-silo 'my stone to be used for a house'

(Class I)

d. lavo'o-xeni 'my stone to be used for breaking nuts' (Class 2)

e. lavo'o-xo 'my stone for a stone oven'

(Hashimoto n.d.:I I)

(Class 3)

Some nouns are obligatorily marked with a genitive class marker, especially bodypart and kinship nouns.

The same morphemes as the possessive suffixes also occur as object markers on verbs in a system of verb classification (Hashimoto n.d.:7-8):

(6) a. na-mai-silo you-look-me 'you look at me'

b. na-iti-xeni you-give-me 'you give me'

c. na-ili-xo you-hang-me 'you hang me'

d. na-vikala-leli you-talk-me 'you talk to me' (Hashimoto n.d.:8-9)

Taulil. Gender is marked in suffixes on nouns and modifiers (see table I), in a prenominal article before names, and in general and possessive pronouns (Laufer I950). There are two genders in all these categories: masculine and feminine, and there is also some evidence of a third person singular neuter general pronoun. We cannot tell what the principles of gender assignment are.

The prenominal article is to before men's names and $e$ before women's names. Some nouns have suppletive stems for singular and plural: vaku-e 'wife', kolotuak 'wives'; or irregular plural suffixes: tipura 'forest', tipurvatak 'forests'(Laufer I950:635). Adjectives agree in gender and number with their head, as in (7).

(7) Lok-a merek-a

man-m good-M

'the good man' (Laufer I950:636)

There are gendered third person pronouns (masculine, feminine, and neuter) in the singular, but gender is not distinguished in the dual or plural. Possessive pronouns have masculine and feminine third person forms in the singular, dual, and plural. There appear to be no neuter possessive forms.

TABLE 1. GENDER SUFFIXES IN TAULIL*

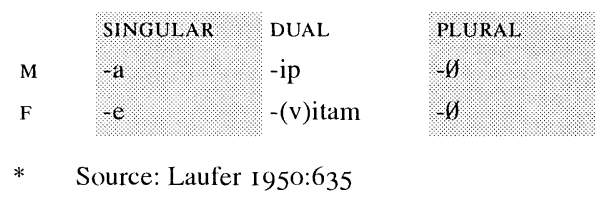


The status of the neuter gender is unclear; there do not seem to be neuter noun suffixes, but there does seem to be a neuter third singular pronoun, as seen for instance in the following example:

(8) Idili-von inda toti belia child-DIM 3SG.N see pig

'the child sees a pig' (Laufer I950:637)

Baining. It is not clear whether Baining consists of one or more languages or interrelated dialects. ${ }^{3}$ For the purposes of this study, which draws upon the work of Parker and Parker (I977), it will be referred to as one language. While this language has gender, the exact nature of the system is not clear. There are definitely two concordial genders; masculine and feminine. There is also evidence of a neuter pronoun, making three genders, although the neuter gender does not show concordance. There is some question whether there might not also be a human/nonhuman distinction in the masculine and feminine genders, thus making a total of five genders (masculine human, masculine nonhuman, feminine human, feminine nonhuman, neuter) (Parker and Parker I977). More data and analysis of agreement morphology are needed to elucidate this.

Personal pronouns distinguish masculine/feminine/neuter in the singular, masculine/feminine in the dual, and human/nonhuman in the plural. Possessive pronouns distinguish masculine/feminine in the singular and dual, and human/ nonhuman in the plural. Demonstratives and indefinite pronouns also distinguish masculine/feminine in the singular and dual, and human/nonhuman in the plural.

There are number/gender suffixes that appear on nouns, adjectives, the numbers one and two (which are adjectives), and interrogatives. Table 2 outlines agreement morphology. It suggests an opposition between four genders: masculine human, masculine nonhuman, feminine human, and feminine nonhuman. The masculine human and masculine nonhuman distinctions are realized by syncretic forms in the singular and dual.

The $b$-initial variants are only for noun stems ending in $m$. Other variants are determined by unknown principles (Parker and Parker 1977:8).

An example of gender agreement in a noun phrase is given in (9).

(9) a vilem-ki ama slur-ki ART pig-F ART big-F

'a big (F) pig' (Parker and Parker I977:I4)

TABLE 2. NUMBER/GENDER SUFFIXES IN BAINING*

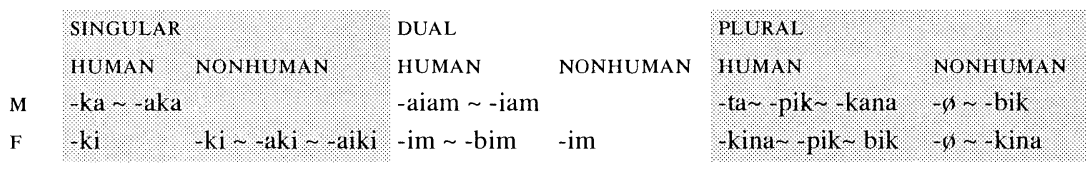

* $\quad$ Source: Parker and Parker 1977:8

3. Work recently begun by Tonya Stes at LaTrobe University will provide answers to these and other questions. 
Modifiers have more or less the same agreement forms as the nouns themselves, except that plural human is $-t a$, and plural nonhuman is - nget (Parker and Parker 1977:13). The articles do not mark gender. They differ in form depending on the word class with which they appear, and other factors. There is no information about the basis on which gender is assigned.

In addition to the gender system, there are six shape-classifiers for count nouns, which can replace these number/gender suffixes. The whole set is shown in table 3 . The $b$-initial variants are only for noun stems ending in $m$.

A few nouns do not take class markers: sleng 'garden(s)', lavu 'ancestors', and so on. And some nouns have irregular plural forms (Parker and Parker I977: I II2). Also, proper nouns do not take classifiers (6).

Kol. The only information we have on gender in Kol is that there are gendered third person pronouns: $3 \mathrm{SG}$ masculine $n i, \mathrm{mo}$, and 3SG feminine no; possessive pronouns 3SG masculine tenti, 3SG feminine rendi (Ross 200I:3 I3).

Kuot. There are two genders, masculine and feminine, manifested in the singular number only, and expressed in agreement and cross-referencing morphology on some or all members of the following classes: third person demonstratives, subject and object verbal cross-references, adjectival subjects, prepositions, and possessives. All nouns are assigned a gender. However, the principles behind the assignment of gender are obscure. Neither gender is unmarked across all domains. In addition, there is a distinction between alienable and inalienable possession marked by different sets of free particles (Eva Lindström, pers. comm., forthcoming).

3.1.1 Comparison of Bismarcks gender morphology. Table 4 shows the morphological material associated with each gender in each Bismarck language. In the final column is information on what function the morphological material has. This is not intended as a comparison of morphemes; rather, it is a comparison of all morphological material associated with gender marking in each language. Comparison between actual morphemes is not fruitful, because there is so much varia-

\section{TABLE 3. SHAPE CLASSIFIERS IN BAINING*}

\begin{tabular}{|c|c|c|c|}
\hline & SINGULAR & DUAL & PLURAL \\
\hline $\begin{array}{l}\text { stick (marks diminution of unit } \\
\text { or fragment) }\end{array}$ & ini & iran & irang. \\
\hline $\begin{array}{l}\text { pole (marks leanness in shape of unit } \\
\text { or segment) }\end{array}$ & -it -bit & $-i \operatorname{sim}$ & -ising \\
\hline chip (marks a segment broken from whole) & : & ligrim & igring \\
\hline $\begin{array}{l}\text { marks thickness or chunkiness of whole } \\
\text { unit }\end{array}$ & -em $\sim$-uum $\sim$-bem & -am $\sim$-bam & -ap -bap \\
\hline marks thickness of segment of a whole unit & & itnem & :itinek: \\
\hline marks flatness of fragment & -es $\sim$-is $\sim$-uus & -uiam & -uaing \\
\hline
\end{tabular}


tion between syntactic functions of gender-marked material. However, it is useful to compare all gender-marked morphology insofar as there is no particular reason to think that syntactic functions are more stable than gender categories. All data in table 4 are taken from the references cited in the text.

Anêm and Ata gender forms are clearly related with $u$ for masculine and $i$ for feminine, and with the feminine $\hat{e} m$, $\hat{\imath} m$ in Anêm and -êm, -im in Ata. Other similarities are less clear. For most of these languages, there is no real gender-associated morphology. Gender-marking forms are mixed up with other categories, so it is not clear-cut to compare forms. Also problematic is the fact that from the paucity of data on some of the languages it is not even clear how many genders they have. Ross (200I; to appear, b) posits a close relationship between Anêm and Ata on the basis of pronouns, and this is certainly borne out in their gender systems. Ross also groups Taulil and Baining together (with Butam) on the basis of their pronouns, but this relationship is not so clear from their gender systems.

TABLE 4. BISMARCKS GENDER MORPHOLOGY

\begin{tabular}{|c|c|c|c|c|}
\hline & MASCULINE & FEMININE & NEUTER & FUNCTION \\
\hline \multirow[t]{4}{*}{ A nển } & 1: $:$ : : : : : : & S: & & concerd in NP \\
\hline & $4:$ : & 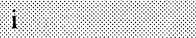 & & realis subject prefix. \\
\hline & do & dê, de & & irrealis subject prefix : \\
\hline & 1. & en. in & & objectupossessive sutfix. \\
\hline \multirow[t]{6}{*}{ Ata } & anu & ane & & free pronoun \\
\hline & mu- & mi- & & perfective agent prefix \\
\hline & $\mathrm{u}-$ & i- & & imperative agent prefix \\
\hline & $-(x) u$ & $-\mathrm{xe}$ & & object suffix \\
\hline & $-\mathrm{u}$ & $-\mathrm{im}$ & & noun class I suffix \\
\hline & -0 & -êm & & noun class 2 suffix \\
\hline \multirow[t]{6}{*}{ Baining } & $(\mathrm{a}) \mathrm{ka}, \mathrm{r}_{1}$ & $(a(1)) l_{1}$ & & singular nominal modifier suffix \\
\hline & alam, $1 \mathrm{lam}$ : : : & $(\mathrm{b}) \mathrm{im}$ & & dual nominal nodifier suffix: \\
\hline & ia, pik, inana, bik & inina, pik. bik. & & plurat nominal modifier suffix. \\
\hline & 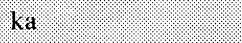 & ki(a) : : : : : : : : : : : : & nge & singular free pronoun : : : : : : : : : \\
\hline & iam & $1 \mathrm{~m} / \mathrm{b}) \mathrm{m}$ & & dual free pronoun: \\
\hline & aa : 8 & (ara: : : : & & possessive pronoun : \\
\hline \multirow[t]{3}{*}{ Taulil } & a & $e^{3}$ & von/inda & singular free pronoun \\
\hline & $-a$ & $-\mathrm{e}$ & & singular noun suffix \\
\hline & -ip & -(v)itam & & dual noun suffix \\
\hline \multirow[t]{2}{*}{$\mathrm{Kol}$} & ni, mo: & no: : : : : : & & free $3 s$ G pronouns \\
\hline & tenti: & rendi & & possessive pronoun. \\
\hline \multirow[t]{3}{*}{ Kuot $^{*}$} & ii & uu & & free pronoun \\
\hline & $-\mathrm{i}$ & $-u$ & & adjective suffix \\
\hline & i- & $u-$ & & demonstrative and linker suffix \\
\hline
\end{tabular}

* There are many more gendered Kuot pronoun forms, too many to cite, but they are mixed up with syntactic function and TAM, and all take the form of single vowels. 
3.2 BOUGAINVILLE. All of the Papuan languages of Bougainville for which we have adequate data have complex systems of nominal classification. Some have classifiers, and some also have gender systems. For Eivo and Nagovisi, we have no data.

Rotokas. There are three genders: masculine, feminine, and neuter. There are gender/number suffixes on nouns, shown in table 5 (Firchow I987:I02). The -to -toa variants are partly morphologically determined. The suffix -riva appears to be an older form, and $-v a$ a newer form, the two of which vary freely. The final $-i$ on the dual forms is lost when a suffix follows (Firchow I987:37).

Gender is marked on nouns, and the suffixes can also be used to nominalize adjectives and a small number of verb roots. "They most commonly occur with the classified noun stems" (Firchow 1987:37). Masculine gender is used for items of mixed masculine and feminine reference; for example:

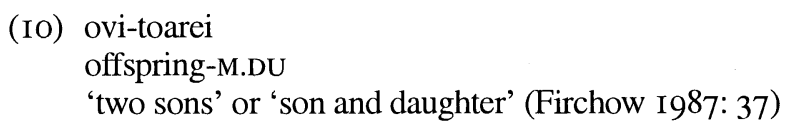

The dual and plural forms of the feminine gender are only used on feminine objects (Firchow 1987: 37). No information is given on membership of the genders, though observations of Firchow's data suggest that male humans seem always to be masculine; female humans seem always to be feminine; 'smoke' and 'coconut tree' are masculine; 'canoe' and 'stone' are feminine; and 'ship' and 'hand' are neuter.

There is also a class system for nominals; there are four shape classifiers (Firchow 1987:36-37), as in (II) and (I2).

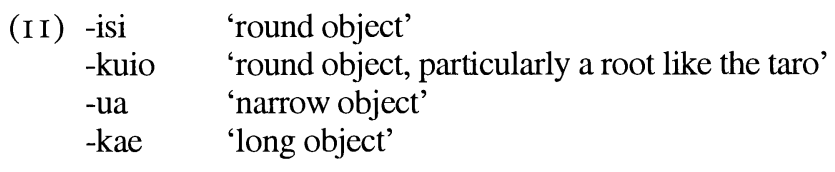

For example:
(I2) a. takura 'egg'
b. rogara 'sand'
takura-isi 'egg'
rogara-ua 'beach' (sand-narrow object)

The classifiers may be used to nominalize adjective roots, for example, riro-isi (large-round object) 'large round object' (Firchow 1987:36).

There are also special pluralizers for different types of objects (47-48). These are perhaps the remnants of an earlier numeral classifier system. See (I3).

\section{TABLE 5. NOMINAL GENDER/NUMBER SUFFIXES IN ROTOKAS}

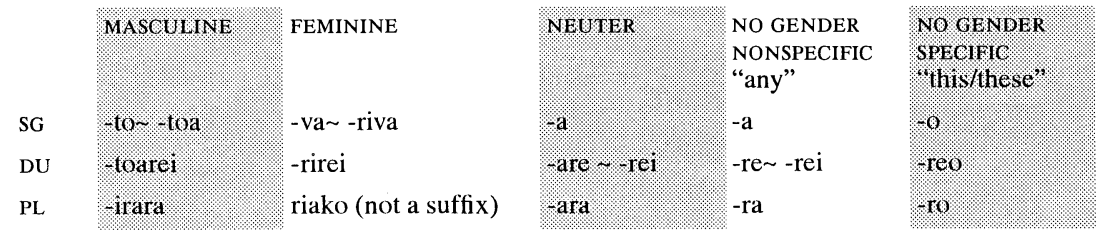




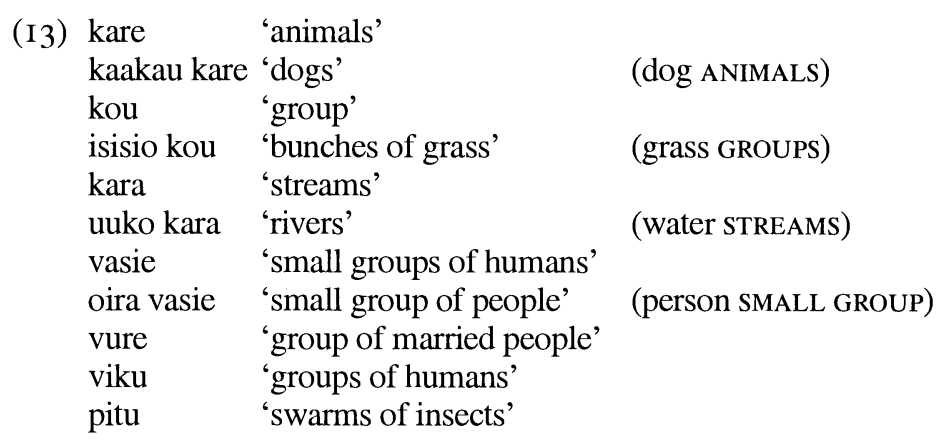

Konua. We know of Konua only that it has gendered third person pronouns, given in table 6 (Ross 200I:3 I5, citing Müller I954).

Motuna. Onishi's (I994, esp. 4.2.I) grammar shows that there are six genders: masculine, feminine, diminutive, local, and - marginally - manner and dual/paucal. Gender is distinguished only in the singular number. Dual/paucal nouns have special forms that fit with the gender paradigms. Plural nouns are marked as masculine.

Gender is marked by agreement nominal dependents, and on verbal cross-referencing material: determiners; possessors and local NPs; some adjectives; one form of the human classifier; the predicates of relative clauses within the same NP; on a suffix on the verb agreeing with the sentence topic; between the Possessee and Possessor or local predicate; and between the argument and some adjectival predicates within the same clause. In addition, a few nouns are marked for gender, all of them kinship terms.

Gender assignment operates to some extent on semantic principles: male things are masculine; female things are feminine. Some human terms can be either gender depending on the sex of the referent (e.g., people, children). Most inanimate nouns are masculine, but they can be treated as diminutive if the speaker wishes. Nouns for small things are often diminutive. Nouns referring to locations, destinations, and temporal entities are local gender (e.g., house, morning), but some nouns can be treated as either masculine or local. There are only a couple of nouns of the manner gender. Dual/plural gender can be used when the speaker wants to avoid specifying the gender of the sentence topic. Masculine is the unmarked gender.

There are also around fifty noun classifiers that may optionally be added to nouns. Classifiers include human, animate, long object, concave object, taro, stone, human habitation, and day, among others (Onishi 1994, chap. 8).

TABLE 6. KONUA THIRD PERSON PRONOUNS

\begin{tabular}{|c|c|c|}
\hline & MASCUI ME & FEMININE \\
\hline FREE & ita & ia \\
\hline SUBJECT & ro & -0 \\
\hline$?$ & - oro. & $-(?) 0$ \\
\hline
\end{tabular}


In addition, there are numeral classifiers: that is, different numerals are used to count different types of nouns. Humans and pigs are counted differently:

(I4) a. no-ro 'ten humans, animates (not pigs)'

b. no-u 'ten pigs'

(I5) a. ki-no-ngo 'twenty humans'

b. ki-u-no 'twenty pigs'

(I6) a. pee-no-ng 'thirty humans, pigs'

b. kori-no-ng 'forty humans' (Onishi 1994:186-187)

Note that the suffixes -ngo and -no are dual number suffixes, and -ng is a paucal/ plural suffix.

Further, there are two numbers for 'five' in Motuna. One form, angumuuka, is used for five of almost anything, and puu is used as in (17) (Onishi 1995: I86).

(I7) 'five pigs, animates' puu-noruu

'five humans' puu-no

'five units of length' puu-ki'

Kinship and classifier possessors are marked differently from other types of possessors. In kinship and classifier possession, a prefix expressing the possessor is prefixed to the kinship word or classifier word. In other types of possession, the possessor is marked by a suffix agreeing with the gender of the possessor (Onishi 1994: 239ff).

Nasioi. There is a class of words (called "projectives," the name a blend of pronoun and adjective) that can modify nouns, stand for nouns, and be modified by nouns (Hurd 1977:III). They obligatorily take case/gender/number suffixes. These suffixes are what could perhaps be thought of as demonstrative-numeral classifiers. Some examples:

(I8) Na-vete nerai' na-rung sipuru'nung. one-side girls one-M he.put.them

'On one side he put only girls.'

(19) Na-ni manikuma te-Ø-ke tavo'kuu'nung. a-lady woman there-at she.arrived

'A/one woman arrived there.' (Hurd I977:I28)

Hurd divides the projectives into semantic categories, for example, social (troupe of dancers/singers; small group of people; mother and child pair, etc.); body parts (strand of hair, limb, arm, etc.); animals (litter of pigs, all the offspring of one cow; share of feast food; tens of pigs, cows; piece of food; etc.); trees and wood (tree, sago frond, sago shingle, paper leaf, feather, board, or plank, etc.); vine and rope (length of rope, etc.). Other supercategories include bamboo; bananas; taro; coconuts: fruit; house, furniture, building materials; containers; clothes; money; implements; physical features; locations; temporals; fractions; kind; word; number. All of these too have many subparts.

Although the glosses of the verbs in the above examples would suggest that some gender at least is cross-referenced in the verb, from Hurd and Hurd (1970) this appears not to be the case. Person markers on verbs do not signal gender. So 
the glosses given here should not be taken to indicate actual gender marked in the verbs. These case/gender/number suffixes are also used as suffixes on other word classes, for example, verbs, nouns, and so forth (Hurd 1977:130). In the following examples, DS stands for derivational suffix.

(20) Kieta-na-ni

Kieta-DS-F.SG

'woman associated with Kieta' or 'Kieta woman'

(2I) ere-na-ru'

blood-Ds-fluid.unit

'drop, container, pool of blood'

(22) pava-na-va

stilt-house-Ds-house

'a stilt house'

(23) tamp-a-u'

good-Ds-taro

'a good taro' (Hurd I977: I3I-I32)

Hurd (1977) contains much more information on the semantic relations between stem and suffix (e.g., they can be used to express possession; to indicate the material from which something is made (I39); part-whole relationships (I39); to indicate the issue of a dispute (I40); on the verbs of relative clauses, to cross-reference the head (I4I-I42); and much more. They can also be suffixed doubly to an invariant twopart stem, to give meanings of multiplicity (I45ff). For example:

(24) a-va-te-va A-house-TE-house

'a great many various houses' (where $a$ - and -te are invariant parts of the construction [Hurd 1977:I47])

It seems clear that the projective system is a classifier system, rather than gender. However, there are also hints that there might also be gender operating; in Hurd and Hurd (I966) there is mention of masculine demonstratives, for instance. Nevertheless, gender is definitely not marked on the verb, and it is not marked on pronouns either. It may be true that Nasioi has a complex combination of gender and classification like Motuna, but this cannot be determined from the materials we have.

Koromira. Koromira is a dialect of Nasioi, but from the information available, it appears different enough from Nasioi to make it worthy of separate consideration. There are at least four genders. For example, demonstratives inflect for masculine and feminine, fruit/animals; things (Rausch I9I2:968). It is not clear whether the demonstratives are marking gender or are classifiers.

There also appears to be a numeral classifier system. There are classes of numerals for fish, birds, fruit, tools, bag-type things, leaves and feathers, canoes, coconuts, and so forth, as shown in table 7.

Buin. There are two genders in Buin. Masculine and feminine are distinguished in third person pronouns, but verbs do not mark the gender of their arguments (Lay- 
cock and Onishi n.d.). Wurm (I978:977) cites the following gender suffixes on nonsingular relationship terms: masculine $-k o,-k i$, -(ga)gi; feminine -(i)to.

Adjectives do not show agreement between masculine or feminine forms, but there is a small class of adjectives that is marked for whether it agrees with a "person, place or thing" (Laycock and Onishi n.d.).

3.2.1 Comparison of Bougainville gender morphology. Table 8 sets out the gender-marking morphological material in each Bougainville language for comparison. Again, this is intended simply as a useful heuristic, to see if there is any material that can be associated with any one particular gender, within a single language or between languages.

It is difficult to see any relationships among the systems of these languages. Both Wurm (I982) and Ross (200I; to appear, b) posit a low-level relationship between Nasioi, Motuna, and Buin (Ross has them in one family; Wurm has Motuna and Buin in one family, Nasioi and Nagovisi in another, and both families in one lower-level subgroup). However, the relationships between them are not apparent from comparison of gender-marking material. Part of the reason probably lies in the paucity of data; for Nasioi we cannot even be sure that there are genders; and much more information on Buin is needed before the situation can be adequately assessed.

3.3 SOLOMON ISLANDS AND ROSSEL ISLAND. All of the Solomon Islands Papuan languages except Santa Cruz have gender systems, but only Äŷiwo arguably shows a classifier system. The Rossel language Yélî Dnye does not have gender (Henderson I995) or classifiers.

Touo (Baniata). ${ }^{4}$ Gender is realized on first, second, and third person pronouns, and on demonstratives, definite and indefinite articles, noun suffixes, and verbal object suffixes. There are four genders: masculine, feminine, neuter I, and neuter 2.

TABLE 7. NUMERAL CLASSIFIERS IN KOROMIRA*

$\begin{array}{lll} & \text { GENERAL NUMBERS } & \text { NUMBERS FOR COUNTING HUMANS } \\ \text { one } & \text { nara } & \text { nárun }(\mathrm{m}) \text {; nara }(\mathrm{f}) \\ \text { two } & \text { keinta } & \text { kéintakära } \\ \text { three } & \text { bäro } & \text { bäreia } \\ \text { four } & \text { káiro } & \text { kaireia } \\ \text { five } & \text { panoko } & \text { uó } \\ \text { ten } & \text { kivora } & \text { nanai } \\ \text { twenty } & \text { keinta kivora } & \text { kenaika } \\ \text { * Source: Rausch i912: } 964 & \end{array}$

\footnotetext{
4. Baniata is the name that has been used in the literature to refer to this language, but speakers themselves prefer the name Touo, as "Baniata" refers to only one of two areas in which this language is spoken (Terrill and Dunn, forthcoming).
} 
The latter two are only distinguished in the singular number, and even there in only some paradigms (i.e., not in object suffixes). The personal pronoun paradigm with gender-marked forms is shown in table 9.

\section{TABLE 8. BOUGAINVILLE GENDER MORPHOLOGY}

\begin{tabular}{|c|c|c|c|c|c|c|c|}
\hline $\begin{array}{l}\text { MASCU- } \\
\text { LINE }\end{array}$ & $\begin{array}{l}\text { FEMI- } \\
\text { NINE }\end{array}$ & NEUTER & $\begin{array}{l}\text { DIMINU- } \\
\text { TIVE }\end{array}$ & LOCAL & MANNER & $\begin{array}{l}\text { DUAL/ } \\
\text { PAUCAL }\end{array}$ & \\
\hline \multicolumn{8}{|c|}{ Roror:As": : : : } \\
\hline $10(\mathrm{a})$ & $(r) v a$ & . & & & & & singular nouns: \\
\hline toarel & rirei & are, rel & & & & & diual nouns: : : \\
\hline irara: & riako & ara $:$ : : : & & & & & plural nouns: \\
\hline$=10$ & 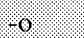 & & & & & & prertos: : : \\
\hline re. & . & & & & & & B.verbs. \\
\hline - & - ere & & & & & & dual pronouns: \\
\hline \multicolumn{8}{|l|}{ KONUA } \\
\hline ita & ia & & & & & & free pronoun \\
\hline -ro & -0 & & & & & & subject pronoun \\
\hline -oro & $-(?) \mathrm{o}$ & & & & & & subject pronoun? \\
\hline \multicolumn{8}{|c|}{ MOTUN: : : : } \\
\hline ong & ana & & 101. & (10100: & . & (1) & denionstrative. \\
\hline 10001500 & iil. & & tir. & 1: & 110.0 & 111 & ?article : : : : : : : : : : : : : : \\
\hline ng: & na & & ni & : & : & . & 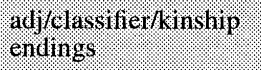 \\
\hline : & : & & n: & - no: & $\sqrt{3.1 .}$ & : & possessor/local NP: \\
\hline 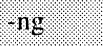 & na & & ni? & no: & nowo & $(n) i$ & verb endings: \\
\hline \multicolumn{8}{|l|}{ BUIN } \\
\hline$-\mathrm{ko}$ & -(i)to & & & & & & $\begin{array}{l}\text { suffixes with relation- } \\
\text { ship terms in } \\
\text { nonsingular numbers }\end{array}$ \\
\hline
\end{tabular}

$-\mathrm{ki}$

-(ga)gi

* Sources: Rotokas, Firchow (1987:19, I02); Konua, Ross (2001, citing Müller 1954); Motuna, Onishi (1944:70); Buin, Wurm (1978:977).

\section{TABLE 9. TOUO PERSONAL PRONOUNS*}

\begin{tabular}{|c|c|c|c|c|}
\hline & SINGULAR & DUAL & TRIAL & PLURAL \\
\hline I EXCL M & \multirow{4}{*}{ yei } & yere & yebenw & \\
\hline I EXCL F & & yerebe & yebenu & yeow \\
\hline I INCL M & & be & menw & \multirow{2}{*}{ menu } \\
\hline I INCL F & & bebe & menu & \\
\hline $2 \mathrm{M}$ & \multirow{2}{*}{ noe } & bere & mebenw & \multirow{2}{*}{ nebw } \\
\hline $2 \mathrm{~F}$ & & berebe & mebenu & \\
\hline $3 \mathrm{M}$ & ZO & zere & nwmw & \multirow{2}{*}{ nw } \\
\hline $3 \mathrm{~F}$ & vo & robe & numw & \\
\hline $3 \mathrm{~N}-\mathrm{I}$ & na & \multirow{2}{*}{ : } & naft & \multirow{2}{*}{ nw } \\
\hline $3 \mathrm{~N}-2$ & ngw & & & \\
\hline
\end{tabular}

* $\quad$ Sources: Todd I 975, Terrill and Dunn fieldnotes 
There are about equal numbers of nouns in each gender, except for neuter 2, which has significantly fewer members than the other genders. Masculine contains mostly nouns referring to male animates, animate objects and plants, and some inanimates. Feminine has mostly female animates, plants, and some inanimates. Neuter I has mostly inanimates, some plants, and a couple of lower animates like 'rat' and 'crab'; Neuter 2 has mostly names of food plants and some utensils (Terrill and Dunn fieldnotes). There is some evidence for feminine being the default gender for gender resolution of mixed gender referents.

Bilua. Obata's (2000) grammar of Bilua states early on that "there are no grammatical genders in Bilua" (7), but later this is expanded to say that "Bilua lacks grammatical gender in nouns, but a gender can be assigned to an NP by an optional NP constituent" (54).

It seems, then, that while nouns are not marked for gender (apart from some kinship nouns), gender is a property of NPs and can be marked by optional constituents within the NP. In addition, gender is marked in pronominal enclitics in the verb phrase that cross-reference these NPs, and by a possessive marker on a possessor NP.

The genders have transparent semantic import; the gender of a noun is construed within the context of the utterance. In Obata's analysis, the only gender recognized is that relating to third person singular humans nouns, which have different morphology for male and female referents. However, while nonhuman nouns are not marked for gender, there is a singulative/nonsingulative distinction that corresponds (in the use of the same morphemes to mark it) to the masculine/feminine gender of human nouns, as in table Io. Note also the morphological paradigm in table I I.

\section{TABLE 10. BILUA DEMONSTRATIVES}

$\begin{array}{lll}\text { DEMONSTRATIVES } & \text { HUMAN } & \text { NONHUMAN } \\ \text { vo } & \text { third person singular masculine } & \text { singulative } \\ \text { ko } & \text { third person singular feminine } & \text { unspecified number }\end{array}$

* Source: Obata 2000: 122 , table 7.5

\section{TABLE 11. BILUA PRONOMINAL ENCLITICS ON MODIFIERS IN A HEADLESS NP*}

\begin{tabular}{|c|c|c|}
\hline PRONOMINAL ENCLITIC & HUMAN & NONHUMAN \\
\hline $\operatorname{la}(3 s \mathrm{~s} \cdot \mathrm{M})$ & third person singular masculine & singulative. \\
\hline$m a$ (3SG.F) & $\begin{array}{l}\text { first person singular } \\
\text { second person singular } \\
\text { third person singular feminine }\end{array}$ & unspecified number \\
\hline nioqa.(3DH): : : : : : : : : : : : : : : : : : & dival & : : : : : : : : : : : : : : : : : : \\
\hline$m u(3 \mathrm{PL})$ & plural & - \\
\hline
\end{tabular}


Such a conflation of gender and number into a single conceptual and morphosyntactic category is further suggested by examples like (25-27) (Obata 2000: I I4).

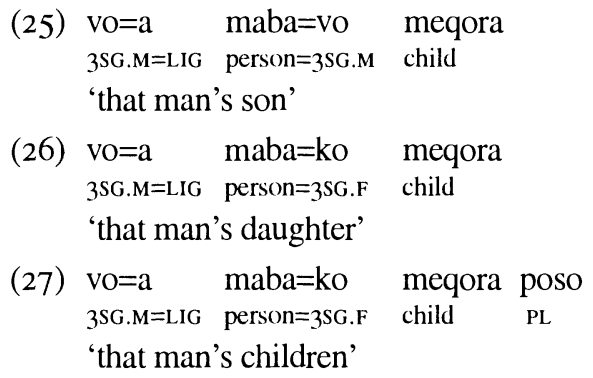

Further, while nonhuman and/or nonthird person singular noun phrases are not overtly marked for gender, modifier phrases headed by them are marked for gender:

(28) enge $=\mathrm{a} \quad$ Solomoni $=\mathrm{a}=\mathrm{ma}$ mabaposo=ngela

I PL.EXCL=LIG Solomon=LIG=3SG.F ${ }^{5}$ personPL=I PL.EXCL

'we, Solomon people'(Obata 2000:97)

(29) $\mathrm{komi}=\mathrm{a}$ peuru $\mathrm{kale}=\mathrm{a}=\mathrm{ma}$ maba madu

PROX.SG.F=LIG village in=LIG=3SG.F person COLL.PL

'people in this village' (99)

(30) komi=a Vella La Vella udu ale

PROX.SG.F=LIG island.name island in

'... in this Vella La Vella island ...' (89)

In addition to the gender system, there is some evidence of what may possibly be the remnants of a noun classification system. There are four "measure pronouns" (59). They occur with a numeral or determiner, and are used for distinguishing different types of things:

(3 I) kena 'whole kumara/taro/yam; piece of banana or fish'

leaza 'crescent-shaped piece of betelnut/cutnut' (i.e., segment)

kobu 'part of an area'

pado 'house/dog/banana/fish/betelnut/person; piece of a long object'

There is a morphological distinction between direct and indirect possession; direct possessive constructions are used for inalienable possession and indirect constructions are used for both alienable and inalienable possession (Obata 2000: I I I).

Lavukaleve. There are three genders, masculine, feminine, and neuter. The so-called masculine class contains, among other things, the nouns that refer to human males; the feminine class contains, among other things, the nouns that refer to human females; and the neuter class contains mostly nonhuman referents (Terrill I999, chap. 6).

Gender is assigned on morphological, phonological, and semantic grounds. Unusually long things are feminine and round things are masculine, rather than

5. Note that the gloss 3SG.F actually means 'not 3SG.M'. 
the other way around, which tends to be more common in languages. The masculine class contains male humans, all animals, some birds, insects, and fish, and many substantial roundish things. The feminine class contains female humans, reptiles, some birds, insects, and fish, many long things, and fruits. The neuter class contains many terms to do with water, time, traditional and sacred things, some body parts, houses and many utensils, and abstract nouns.

All nouns have an inherent gender, but this gender is not marked overtly on nouns (although there is some relationship between gender and dual and plural suffixes on nouns). All modifiers in an NP (except for possessors and a few other minor lexically-determined exceptions) agree in gender with the head noun. That is, gender is marked on adjectives, demonstratives, and the definite article. In addition, most clausal elements that cross-reference to a nominal argument are also marked for the gender of their nominal argument. So object prefixes, the agreement suffix, and the focus markers are also marked for the gender of the noun to which they refer. Gender is a category in singular and dual numbers, but not in the plural. Here are some examples showing gender-related morphology (Terrill fieldnotes):

(32) Ngai nei rogel a-le-gel figel.

ISG coconut(N) unit.DU.N ISG.S-see-DU.N 3DU.N.FOC

'I saw two coconuts.'

(33)
Vo'vou na
si'val o-le-m
fin.
boy(M) SG.M.ART mango(M) 3SG.SUBJ-see-SG.M 3SG.M.FOC

'The boy saw a mango.'

(34)

$\begin{array}{lllll}\text { Okala la feo } & \text { tuane-a } & \text { heo. } \\ \text { 3SG.POSS-mother(F) } & \text { SG.F.ART } & \text { 3SG.F.FOC } & \text { be.big-SG.F } & \text { 3SG.F.EFOC } \\ \text { 'His mother is big.' } & & & \end{array}$

In addition to its gender system, and possibly relevant to a discussion of ways of classifying nouns, Lavukaleve has a small group of nouns that refer to a quantity of ten of various culturally important things. Some of these nouns include feil 'ten dogs'; koku 'ten possums'; kolo 'ten pigs'; lolu 'ten fish'; legom 'ten coconut crabs'; baem 'ten bonitos'; tafor 'ten arm-rings'. These words are regular nouns; they are singular, they have gender, and they have dual and plural forms as do ordinary nouns (Terrill I999:52-53). This is possibly evidence of the last remnants of a numeral classifier system.

Savosavo. There are two genders: masculine and feminine. Male humans and other things are masculine; female humans and other things are feminine. Most nouns "denoting objects without sex" are masculine (Todd I975:8IO).

Gender is marked in prenominal articles only in the singular, not in the dual or plural. Other nominal words also mark gender, as do two verbal auxiliaries.

Äŷiwo. In Santa Cruz proper, there is neither gender nor classifiers (Wurm 1982). However, Âyiwo has two systems of noun classes: Wurm (I98I) calls these the variable and fixed noun-class systems, respectively. 
The variable noun-class system has 32 classes (39 in Wurm 1992). Nouns are formed by a class prefix plus a base. Bases are verbal in nature. Many of the prefixes do not occur independently, but some are identical to independent nouns, and some appear to be shortened or altered nouns. The classes are semantically relatively transparent. Five of them are typically gender-like in meaning: masculine, feminine, neutral, neutral-collective, mutable. Others mean things like 'cutnut class', 'chicken class', 'fruit class', 'basket class', and so on. Some bases can occur with many different prefixes (e.g., base $v a$ 'to be immature' can appear with different class markers as giva 'male human baby'; sîva 'female human baby'; meva 'human babies (collective)'; väva 'small chicken'; bova 'tiny shark'; uva 'tiny banana' (Wurm I992: I49). A small proportion of these variable noun classes exhibit concord, according to four different patterns (Wurm 1992:150). Five classes show concordance within NPs, with attributive adjectives, numerals, and possessives. Four classes show agreement with adjectives and emphasized possessives, and-to a limited extent-numerals. Five classes show agreement only with adjectives, and rarely numerals. Two classes show agreement only with numerals. The rest of the classes do not have class concordance at all. In any case, there is no evidence of gender in pronouns, gender is not marked in verbal cross-referencing, and noun-adjective concordance is apparently optional and clearly rudimentary when it occurs (see also Lincoln I978).

Separate from this system is the so-called fixed noun-class system, under which all nouns are assigned to one of eight individual noun classes. Again, these nouns consist of prefix plus base, but these bases, unlike those in the variable noun-class system, are mostly nouns. The fixed noun classes do not show concordance with other elements inside the NP. It is not clear whether there is further concordance beyond the NP in the clause with either of these types of class systems. It is possible that at least some of the variable noun classes might be alternatively analyzed as either a historical process of word formation; or, perhaps as a synchronic process of derivation of nouns from verbs.

Wurm's (I972, I98I) description of the "possessive class systems" of the nonAustronesian languages of Santa Cruz seems to be similar to an alienable/inalienable distinction in possessive marking. His "construct possessive class system" (I976), described as a feature of all the non-Austronesian languages of Santa Cruz, appears to be also analyzable as one of nominal compounds.

3.3.1 Comparison of Solomon Islands gender morphology. Table I 2 shows the morphological material associated with each gender in each Solomon Islands language. In the final column is information on morphological function.

Note that the genders are not completely commensurate. While each language has a gender associated with male humans and other things, and one with female humans and other things, Touo (Baniata) has two other genders, and Lavukaleve has one other. Touo's neuter I contains mostly inanimates; hence its name. The neuter 2 class is only distinguished in a small proportion of morphological paradigms.

Even the masculine and feminine genders in each language are not completely commensurate. In Bilua, gender is completely transparent semantically, and apart 
from humans, which have inherent gender, other nouns appear to be assigned gender on a case-by-case basis, depending on the context. Similarly, but at a lesser extreme, the other languages have a basic core semantic meaning for each gender, and many other semantic possibilities. However, it is still useful to compare gender functions, precisely because each of the Central Solomon Islands languages do have at least two genders, two of which do share a basic semantic core

The congruence between the Bilua and Savosavo forms is striking. In both languages $l \mathrm{~V}$ and $v \mathrm{~V}$ mark masculine gender and $m a$ and $k o$, feminine gender. The exact nature of the morphological material that each form marks differs in the two languages, but it is noteworthy that the formatives associated with each gender are quite similar or the same.

Bilua has a completely regular and semantically transparent gender system involving only four formatives in all to make the gender distinctions. That is, gender is marked with the same material in many different word classes. This makes it look like a relatively young system: in general, diversity of forms and semantic opacity are associated with ancient systems. However, if the similarities in the Bilua and Savosavo systems are due to shared origin (whether genetic or contact), then presumably the system is not as young as it looks. It may be the result of relatively recent regularization of ancient material, for instance.

The diversity of the gender-marking material in Touo (Baniata) is a case in point. In general, there is very little correspondence between gender-marking material in

TABLE 12. SOLOMON ISLANDS GENDER MORPHOLOGY*

\begin{tabular}{|c|c|c|c|c|c|}
\hline & MASC & FEM & NEUTER I & NEUTER 2 & FUNCTION \\
\hline \multirow[t]{3}{*}{ favakaleve } & 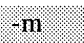 & $-a$ & .0 & & adj agreement \\
\hline & na & 19. & ga & & demonstrative, article \\
\hline & a. & 0. & e. & & pronoun prefixes: \\
\hline \multirow[t]{6}{*}{ Touo (Baniata) } & zo & vo & na & ngw & pronouns \\
\hline & $-r$ & $-\mathrm{v}$ & $-\varnothing$ & & object suffix \\
\hline & $\mathrm{m}$ & $\mathrm{n}$ & & & plural pronoun \\
\hline & zere & robe & rede & & dual pronoun \\
\hline & zo & $\mathrm{ma}$ & na & ngw & indefinite article \\
\hline & $-\mathrm{zo}$ & $-\mathrm{mi}$ & - na & $-n g w$ & demonstratives \\
\hline \multirow[t]{2}{*}{ Billia } & 10,1 & na & : : : : & & pronoun enclitic \\
\hline & $10 \%$ & ino & & & object linic : : : \\
\hline \multirow[t]{4}{*}{ Savosavo } & 1 & $\mathrm{k}$ & & & object pronoun clitic \\
\hline & lo & ko & & & article \\
\hline & $-v a$ & $-\mathrm{ma}$ & & & possessive suffix \\
\hline & li/lo & $\mathrm{k}$ & & & verbal object affix \\
\hline Aywo: & : & $81:$ : si? & a a (animal) & ne (nellective) & Wurm $1978 \% 976$, : \\
\hline
\end{tabular}

* Orthography note: Touo $r$ is [1], $w$ is [o], $n g$ is [n]. Lavukaleve $g$ is a velar approximant. Âyiwo $\hat{\imath}$ is "whispered" [i]; $\hat{y}$ is "whispered" [y]; $\ddot{a}$ is [æ]. 
different word classes, or even in different numbers within a word class. Ross (to appear, b:I8I) claims that the Touo vo 'feminine' (which he reconstructs as *vo) is cognate with Bilua vo and Savosavo $v a$, both masculine; he suggests "there has been an apparent cross-over" in the genders. (Wurm [1978:977] first proposed this idea.) However, perhaps more significant is the Touo (Baniata) feminine ma compared with Bilua feminine $m a$ and Savosavo feminine $m a$; and Touo masculine $r$ (a lateral flap) with Bilua masculine $l a$ and Savosavo masculine $l$, $l o$, $l$.

The Touo case is much weaker than the Bilua-Savosavo case, because there are many morphemes left unaccounted for. There are so many morphemes involved that it is not a situation in which one or a few in particular are associated with each gender.

With respect to Lavukaleve, one could perhaps posit a connection between feminine $l$ with the masculine $l / r$ of the other languages; and between masculine $m$ and feminine $m$ of the other languages; but the kind of crossover this would entail, with two genders but not the third changing function, seems dubious. The more cautious stance taken here is to conclude that Lavukaleve has no obvious shared gender markings.

Äyiwo, too, is left out of the picture: there are no convincing parallels between Äyiwo forms and forms in any of the Central Solomons languages. Note that Wurm (1978:977) posits a relationship between Touo (Baniata) and Savosavo forms with

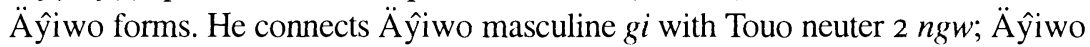
feminine si with Touo masculine $z, o$; Äyiwo animal vä with Touo feminine vo; and $\ddot{A} \hat{y} i w o$ neutral-collective $m e$ with Touo plural mo. Further, Wurm connects Äŷiwo masculine gi with Savosavo feminine $k e$; $\ddot{A}$ ŷiwo feminine si with Savosavo masculine le; and Äŷiwo neutral-collective $m e$ with Savosavo plural $m e$. Many of these connections seem rather ad hoc (e.g., le : si). Also, the massive crossovers posited are difficult to validate. In short, there is no convincing formal evidence to link the gender morphology of Äŷiwo with that of any Central Solomons language.

It is important to state again that the foregoing is not intended as a comparison of morphemes; rather, it is a comparison of all morphological material associated with gender marking. It is not fruitful to compare lexical cognates to find if they have the same genders, because there just are not enough cognate lexemes in these languages. These languages share only around Io percent vocabulary (Tryon and Hackman I983), almost all of which is transparent Austronesian loans. There are not enough cognate-looking nouns with known genders to make comparison meaningful.

4. DISCUSSION. The motivation behind the foregoing discussion, apart from description of the nominal classification systems of these languages, is to attempt to shed light on the question of whether in the systems of nominal classification we can see any evidence of shared inheritance in any or all of these languages. In one sense, this is an unattainable goal. These languages have possibly been more or less in place for up to 35,000 years-far beyond the applicability of our best methodological apparatus, the comparative method of reconstruction. The first human occupation of Island Melanesia, presumably by people speaking ancestors of some if not all of the current East Papuan languages, is currently thought to have been from 29,000 
to more than 35,000 years ago (Spriggs 1997). By contrast, speakers of Austronesian languages are thought to have first arrived in the area approximately 3,500 years ago (Ross I988; Kirch I997).

However, we do not need to be too pessimistic solely on account of the vast time depth. Of course, we cannot find similarities between languages dating back 35,000 years ago. But similarities between these languages do not have to go back 35,000 years. In fact, it is likely that some, if not all, of these languages separated from each other much later than that. Further, these languages have had a shared history presumably all along, if not through genetic relationships, then quite possibly through contact. Indeed, it might be true that we could ultimately find evidence for a pre-Austronesian Sprachbund among them.

Almost all the East Papuan languages for which we have adequate information do show some way of classifying nouns into morphological agreement classes. The conclusions to be drawn from this are not immediately obvious. The forms of gender-marking morphology suggest a relationship between some of the central Solomon Islands languages, and formal and structural similarities also exist between Anêm and Ata in New Britain.

However, further similarities, either formal or structural, are not apparent between the systems of nominal classification in the other East Papuan languages. Given this, it is hazardous to use the existence of systems of nominal classification as evidence of shared inheritance. Nominal classification systems could have arisen in these languages not just through inheritance, but either as a result of chance, or, more likely than chance, through contact-induced diffusion.

In this respect, it is significant that there are Oceanic languages bordering on some of these East Papuan languages that have developed gender systems-languages such as Teop in north Bougainville (Mosel and Spriggs 1999) and some languages of west New Britain, namely the Pasismanua communalects, and Bebeli, Akolet, Avau, and Atui (Ross 1988: 183).

To show relationship of common origin due to inheritance or to contact, we would expect to find certain commonalities in the forms used to mark gender, or in the systems themselves. If we do find such similarities, we can use these to confirm the earlier hypotheses. If no commonalities are found between the gender systems of these languages, we cannot use the presence of gender as a criterion for the relationship (by genetics or contact) of the East Papuan languages.

Importantly, this study has shown that we cannot safely conclude from the mere existence of nominal classification systems in a group of nearby languages that these nominal classification systems must necessarily stem from the same source, and therefore that the languages that have them likewise stem from the same source. In fact, the nominal classification systems exhibited in these languages show a great deal of variety, and it is by no means clear that-apart from some of the Central Solomons languages, on the one hand, and Anêm and Ata on the other-there is any relationship between them at all. Wurm (1975, I982) and Capell (1962) saw gender as one of the best pieces of evidence for the relationship of these languages. However, the present study has found that while gender, or 
nominal classification more generally, is prevalent, the systems are so divergent as to be in many cases incommensurate. There is little evidence by way of formal similarities to encourage the hypothesis of wider genetic relationship between the East Papuan languages.

A more cautious position that the existence of gender may be evidence of linguistic contact is more plausible, in that it is possible for grammatical systems to be borrowed in the absence of borrowing of actual forms. This is certainly the simplest account of why these nearby languages have nominal classification systems. However, without actual evidence of borrowing, this conclusion is no more than a plausible hypothesis.

\section{REFERENCES}

Aikhenvald, Alexandra Y. 2000. Classifiers: A typology of noun classification devices. Oxford: Oxford University Press.

Capell, A. I962. Oceanic linguistics today. Current Anthropology 3:37 I-428.

Corbett, Greville. I99I. Gender. Cambridge: Cambridge University Press.

Dixon, R. M. W. I982. Noun classifiers and noun classes. In Where have all the adjectives gone? and other essays in semantics and syntax, ed. by R. M. W. Dixon, 2 I I233. Berlin: Mouton de Gruyter.

1986. Noun classes and noun classification in typological perspective. In Noun classes and categorization, ed. by C. G. Craig, I05-I I2. Amsterdam: John Benjamins.

Dunn, Michael, Ger Reesink, and Angela Terrill. 2002. The East Papuan languages: A preliminary typological appraisal. Oceanic Linguistics 4I:28-62 [this issue].

Firchow, Irwin B. 1987. Form and function of Rotokas words. Language and Linguistics in Melanesia I 5:5-I I I.

Grinevald, Colette. 2000. A morphosyntactic typology of classifiers. In Systems of Nominal Classification, ed. by Gunter Senft, 50-92. Cambridge University Press.

Hashimoto, Kazuo. n.d. Ata grammar essentials. Unpublished manuscript. Summer Institute of Linguistics.

Henderson, James. 1995. Phonology and grammar of Yele, Papua New Guinea. Series BI I 2. Canberra: Pacific Linguistics.

Hurd, Conrad. 1977. Nasioi projectives. Oceanic Linguistics I6: I I I-I 78.

Hurd, Conrad, and Phyllis Hurd. 1966. Nasioi language course. Port Moresby: Department of Information and Extension Services.

- 1970. Nasioi verbs. Oceanic Linguistics 9:37-78.

Keesing, Roger M. 1985. Kwaio grammar. Series B-88. Canberra: Pacific Linguistics.

Kirch, Patrick. 1997. The Lapita peoples. London: Blackwell.

Laufer, Carl. 1950. Die Taulil und ihre Sprache. Anthropos 45:627-640.

Laycock, Donald, and Masa Onishi. n.d. Elementary Buin grammar, edited. Unpublished ms.

Lincoln, Peter C. 1978. Reef-Santa Cruz as Austronesian. In Second International Conference on Austronesian Linguistics: Proceedings, ed. by Stephen A. Wurm and Lois Carrington, 929-967. Series C-61. Canberra: Pacific Linguistics.

Lindström, Eva. Forthcoming. Topics in the grammar of Kuot, a non-Austronesian language of New Ireland, Papua New Guinea. Ph.D. thesis, Stockholm University.

Lynch, John. I998. Pacific languages: An introduction. Honolulu: University of Hawai'i Press. 
Nichols, Joanna. 1992. Linguistic diversity in space and time. Chicago: University of Chicago Press.

Mosel, Ulrike, and Ruth Spriggs. 1999. Gender in Teop (Bougainville, Papua New Guinea). In Gender in grammar and cognition, ed. by Barbara Unterbeck, Matti Rissanen, Terttu Nevalainen, and Mirja Saari, 32 I-349. Berlin: Mouton de Gruyter.

Müller, Adam. I954. Grammatik und Vokabular der Konua-Sprache. Micro-Bibliotheca Anthropos I2. Anthropos Institut.

Obata, Kazuko. 2000. A grammar of Bilua, a Papuan language of the Solomon Islands. Ph.D. thesis, Australian National University.

Onishi, Masayuki. I994. A grammar of Motuna (Bougainville, Papua New Guinea). Ph.D. thesis, Australian National University.

Parker, Jim, and Diana Parker. I977. Baining grammar essentials, part I (stems, words, phrases). Unpublished manuscript. Summer Institute of Linguistics.

Rausch, J. I9I2. Die Sprache von Südost-Bougainville, Deutsche Salomoninseln. Anthropos 7:105-I 34, 585-6I6, 964-994, I056-I057.

Ross, Malcolm D. I988. Proto Oceanic and the Austronesian languages of Western Melanesia. Series C-98. Canberra: Pacific Linguistics.

. 200I. Is there an East Papuan phylum? Evidence from pronouns. In The boy from Bundaberg: Studies in Melanesian linguistics in honour of Tom Dutton, ed. by Andrew Pawley, Malcolm Ross, and Darrell Tryon, 30 I-32 I. Canberra: Pacific Linguistics.

- To appear, a. Defining the Trans New Guinea Phylum: Preliminary evidence from pronouns. In Papuan languages and the Trans New Guinea Phylum, ed. by Andrew Pawley, Malcolm Ross, and Meredith Osmond. Canberra: Pacific Linguistics.

- To appear, b. Pronouns as preliminary evidence for grouping Papuan languages. In Papuan languages and the Trans New Guinea Phylum, ed. by Andrew Pawley, Malcolm Ross, and Meredith Osmond. Canberra: Pacific Linguistics.

Spriggs, Matthew. I 997. The Island Melanesians. London: Blackwell.

Terrill, Angela. 1999. Lavukaleve: A Papuan language of the Solomon Islands. Ph.D. thesis, Department of Linguistics, Research School of Pacific and Asian Studies, Australian National University. [To appear in the Mouton Grammar series, Mouton de Gruyter.]

Terrill, Angela, and Michael Dunn. Forthcoming. Orthographic design in the Solomon Islands: The social, historical, and linguistic situation of Touo (Baniata). Written Language and Literacy.

Tharp, Doug. 1996. Sulka grammar essentials. In Two non-Austronesian grammars from the islands, ed. by John M. Clifton, 77-I 79. Data Papers on Papua New Guinea Languages, Volume 42. Ukarumpa: Summer Institute of Linguistics.

Thurston, William R. 1982. A comparative study in Anêm and Lusi. Series B-83. Canberra: Pacific Linguistics.

Todd, Evelyn M. I975. The Solomon language family. In New Guinea area languages and language study, vol. I, Papuan languages and the New Guinea linguistic scene, ed. by Stephen A. Wurm, 805-846. Series C-38. Canberra: Pacific Linguistics.

Tryon, D. T. and B. D. Hackman. 1983. Solomon Island languages: An internal classification. Series C-72. Canberra: Pacific Linguistics.

Wurm, Stephen A. 1972. Notes on the indication of possession with nouns in Reef and Santa Cruz Island languages. Papers in the Linguistics of Melanesia no.3. Series A35, 85-I 13. Canberra: Pacific Linguistics.

- 1975. The East Papuan Phylum in general. In New Guinea area languages and language study, vol I, Papuan languages and the New Guinea linguistic scene, ed. by Stephen A. Wurm, 783-804. Series C-38. Canberra: Pacific Linguistics.

. 1976. The Reef Island/Santa Cruz family. In New Guinea area languages and language study, vol. 2, Austronesian languages, ed. by Stephen A. Wurm, 637-674. Series C-39. Canberra: Pacific Linguistics. 
1 978. Reefs-Santa Cruz: Austronesian, but...! In Second International Conference on Austronesian Linguistics: Proceedings, ed. by Stephen A. Wurm and Lois Carrington, 969-I I o. Series C-6I. Canberra: Pacific Linguistics.

. I98I. Notes on nominal classification in Äŷiwo, Reef Islands, Solomon Islands. In Linguistics across continents, ed. by A. Thomas and D. Gonzales, 123I42. Manila: Linguistic Society of the Philippines.

1982. Papuan languages of Oceania. Ars Linguistica 7. Tübingen: Gunter Narr Verlag.

I992. Change of language structure and typology in a Pacific language as a result of culture change. In Culture change, language change: Case studies from Melanesia, ed. by Tom Dutton, I 4I-I 57. Series C-I 20. Canberra: Pacific Linguistics.

Yanagida, Tatsuya. 2000. Basic clause structure of the Ata language. Seminar handout, Department of Linguistics, Research School of Pacific and Asian Studies, Australian National University, Wednesday, April 26.

Angela Terrill

Centre for Research on

Language Change

Australian National University

Acton ACT 0200

Australia

angela.terrill@mpi.nl 